\title{
Analysis of Lavender Aroma and Guided Imagery on Insomnia in Lansia in Technical Specific Unit Social Tresna Wherda Glenmore District Banyuwangi
}

\section{Grenda Aprilyawan}

Magister of Public Health Program of Stikes Surya Mitra Husada Kediri

Email:

grenda262@gmail.com
Received: March 12, 2019

Accepted : April 13, 2019

Published : May 10, 2019

\begin{abstract}
Naturally the elderly is experiencing a decline both in terms of physical, biological and mental and this is not independent of economic, social and cultural issues. Sleep disorders is one of the health problems often faced by the elderly. The elderly require good sleep quality to improve health and restore the condition of the illness. There are several ways to deal with insomnia can be done in 2 ways: pharmacology and non pharmacology. The purpose of this study was to determine the effect of lavender and guided imagery on insomnia in elderly in Technical Implementation Unit (UPT) of Social Tresna Werdha Glenmore Sub-district of Banyuwangi Regency. In this research, the research design used is True experimental research design. The population of the study were all elderly people who experienced insomnia of 36 people and sample of 33 people by using simple random sampling. Data collection using checklist sheet then analyzed using Cochran test. The results showed that significant probability value of Cochran test of 0,032<0,05 means there is significant difference between giving of lavender scent, guided imagery and control group to insomnia. While the treatment before and after the lavender scent there is a significant influence on insomnia (p: $0.008<0.05$ ). Treatment before and after guided imagery there is a significant effect on insomnia (p: $0,016<0,05$ ). Treatment before and after the control group there was no significant effect on insomnia (p: 0,500>0,05). Based on the results of this study non pharmacology treatment can be maintained and continued for better sleep quality. Whether using aroma therapy or guided imagery lavender because it has been proven to reduce insomnia.
\end{abstract}

Keywords: Aroma therapy, guided imagery, insomnia

\section{(9) (1) (}

This is an open-acces article distributed under the terms of the Creative Commons Attribution-ShareAlike 4.0 International License.

\section{INTRODUCTION}

The process of aging (aging) is procces natural that human encountered where a decline or change in the physical, emotional, psychosocial, which will certainly affect productivity. Naturally the elderly is experiencing a decline both in terms of physical, biological and mental and this is not independent of economic, social and cultural issues. Decreased function of various elderly organs into 
a range of diseases that are acute or chronic. There is a tendency of degenerative diseases, metabolic diseases, psychosocial disorders and infectious diseases increases (Luthfa, 2015).

One such disorder is a change in sleep patterns (insomnia), during sleep pattern aging will undergo distinctive changes that distinguish from younger people, those changes include latent phase of sleep, waking up in the early hours, increasing the number of naps and difficulty to sleep that makes the patient feel not getting enough sleep when awakened (Sulistyarini, 2016). The phenomenon that occurs in the Technical Implementation Unit (UPT) of Social Tresna Werdha Glenmore, has not determined a definite protap to handle insomnia.

About a quarter of the adult population has experienced sleeping problems and $6 \%$ to $10 \%$ are thought to have insomnia disorders (National Sleep Foundation, 2012). A survey of Warwick Medical School from the UK on Country Country in Africa and Asia gained about 150 million adults suffered from sleep disorders. An average of $16.6 \%$ of cases of insomnia among the countries surveyed. This figure approaches the western country of about 20\% (Prasetya, 2016). In Indonesia, in 2010 found $36 \%$ for elderly men and $54 \%$ elderly women complained about insomnia. Only $26 \%$ of elderly men and $21 \%$ of elderly women reported no difficulty sleeping (Zeidler, MR, 2011).

In East Java the incidence of elderly insomnia in 2010 reached about $10 \%$ of the total number of elderly people in East Java and 3\% of them suffered serious problems (Kurniawan, 2012). From the data of the Central Bureau of Statistics in 2011 the number of elderly in Banyuwangi which amounted to 189,397 people and preliminary study results in Elderly Service Courtesy Glenmore obtained data on the number of elderly about 70 elderly. While the results of interviews from 15 elderly, 10 elderly said experiencing sleep disturbances and 5 people did not experience sleep disorders.

Sleep disorders is one of the health problems often faced by the elderly. This condition requires serious attention. Poor quality of elderly sleep is due to increased sleep latency, reduced sleep efficiency and early awakening due to aging process. The aging process causes decreased neurontransmitter function charac-terized by decreased norepinephrine distribution. It causes a change in circadian rhythm, where elderly sleep changes in the NREM 3 and 4 phase's elderly almost do not have phase 4 or sleep in (Khasanah and Hidayati, 2012).

There are several ways to deal with insomnia can be done in 2 ways: pharmacology and nonpharmacology. One non-pharmacological way to reduce insomnia is the aroma of lavender therapy and guided imagery. Aromatherapy is a method of treatment through odorless media derived from certain plant material. Aromatherapy has many health benefits. Aromatherapy can be beneficial for those suffering from some mental disorders. The benefits of essential oils for physical and mental balance are extraordinary. The aroma and softness of essential oils can overcome physical and psychological complaints. By smelling the olive oil from the essential oil of the sense of smell can stimulate our emotional memory by giving a physical reaction of behavior. The scent of lavender has a strong and fragrant odor. Used to facilitate sleep, help regulate heart rate, and insomnia (Lestari, 2016). Aromatherapy using lavender oil can reliably provide a relaxing effect for the nerves and muscles that are tense (carminative) after exhaustion on the move. Lavender flowers also have the effect of giving drowsiness (sedative) (Sianipar, 2017).

Likewise with relaxation with guided imagery techniques will make the body more relaxed and comfortable in sleep. By doing deep breath slowly, the body will become more relaxed. Relaxed feelings will be forwarded to the hypothalamus to produce Corticotropin Releasing Factor (CRF). Furthermore, CRF stimulates the pituitary gland to increase the production of Proopioidmelanocortin (POMC) so that the enkephalin production by the adrenal medulla increases. The pituitary gland also produces endorphins as neurotransmitters that affect the mood to relax (Guyton and Hall, 2010). Based on the above description, researchers are interested to examine "Analysis of lavender scent and guided imagery on Insomnia in the Elderly in Technical Implementation Unit (UPT) Social Tresna Werdha Glenmore District Banyuwangi District".

\section{MATERIALS AND METHODS}

The design used in this research is True experimental. Population is all elderly who experienced insomnia in UPTD Elderly Glenmore Banyuwangi 2018, a number of 36 people. The sample size is 33 respondents using simple random sampling technique. Independent research variables are lavender scent, guided imagery and control group. Dependent variable is insomnia. Data 
were collected using checklist, then the data were analyzed using Cochran test with the significance level of $\alpha \leq 0.05$.

\section{RESULTS}

Table 1. Frequency distribution based on insomnia before first day and after the last day giving aroma lavender

\begin{tabular}{ccccc}
\hline \multirow{2}{*}{ Aroma } & \multicolumn{2}{c}{ Before } & \multicolumn{3}{c}{ After } \\
\cline { 2 - 5 } & $\mathrm{n}$ & $\mathrm{f}(\%)$ & $\mathrm{n}$ & $\mathrm{f}(\%)$ \\
\hline No Insomnia & - & - & 3 & 72,7 \\
\hline Insomnia & 11 & 100 & 11 & 27,3 \\
\hline Total & 11 & 100 & & 100 \\
\hline
\end{tabular}

Source: Primary data of research in 2018

Based on table 1. shows that from 11 respondents before giving lavender scent the majority experience insomnia that is as much as 11 respondents (100\%), and after giving of lavender scent mostly insomnia that is not as much as 8 respondent $(72,7 \%)$.

Table 2. Frequency distribution based on insomnia before first day and after last day giving guided imagery

\begin{tabular}{ccccc}
\hline \multirow{2}{*}{ Guided Imagery } & \multicolumn{2}{c}{ Before } & \multicolumn{2}{c}{ After } \\
\cline { 2 - 5 } & $\mathrm{n}$ & $\mathrm{f}(\%)$ & $\mathrm{n}$ & $\mathrm{f}(\%)$ \\
\hline No Insomnia & - & - & 7 & 63,6 \\
\hline Insomnia & 11 & 100 & 11 & 36,4 \\
\hline Total & 11 & 100 & 100 \\
\hline
\end{tabular}

Source: Primary data of research in 2018

Based on table 2. shows that of 11 respondents before the guided imagery the majority experienced insomnia that is as much as 11 respondents (100\%), and after guided imagery most of the insomnia did not experience as many as 7 respondents $(63.6 \%)$.

Table 3. Frequency distribution based on insomnia before first day and after last day control group

\begin{tabular}{ccccc}
\hline \multirow{2}{*}{ Control Group } & \multicolumn{2}{c}{ Before } & \multicolumn{2}{c}{ After } \\
\cline { 2 - 5 } & $\mathrm{n}$ & $\mathrm{f}(\%)$ & $\mathrm{n}$ & $\mathrm{f}(\%)$ \\
\hline No Insomnia & - & - & 2 & 18,2 \\
\hline Insomnia & 11 & 100 & 9 & 81,8 \\
\hline Total & 11 & 100 & 11 & 100 \\
\hline
\end{tabular}

Source: Primary data of research in 2018

Based on table 3 shows that of the 11 respondents before the control group the majority experienced insomnia as many as 11 respondents (100\%), and after treatment (control group) mostly experienced insomnia that is as much as 9 respondents $(81,8 \%)$. 
Table 5 Cochran Test

\section{Frequencies}

\begin{tabular}{cll}
\hline & & Value \\
\cline { 2 - 3 } & 0 & 1 \\
\hline Lavender & 8 & 3 \\
\hline Guided.Imagery & 7 & 4 \\
\hline Control & 2 & 9 \\
\hline
\end{tabular}

Test Statistics ${ }^{\mathrm{a}}$

\begin{tabular}{cc}
\hline $\mathrm{N}$ & 11 \\
\hline Cochran's Q & $6,889^{\mathrm{a}}$ \\
\hline Df & 2 \\
\hline Asymp. Sig. &, 032 \\
\hline
\end{tabular}

a. 0 is treated as a success

Based on the result / output above, we get significant probability value equal to 0,032 . Because of the significant probability value $0.032<0.05$ then the hypothesis Ho is rejected and $\mathrm{Ha}$ accepted, meaning there is a significant difference between the provision of lavender scent, guided imagery and control group against insomnia in UPT Social Service Tresna Werdha Glenmore Banyuwangi District.

To determine which groups are most influential then tested Mcnemar .

Test Statistics ${ }^{\mathrm{a}}$

\begin{tabular}{cccc}
\hline \multirow{2}{*}{$\mathrm{N}$} & \multicolumn{3}{c}{ Before \& After } \\
\cline { 2 - 4 } & Lavender & Guided Imagery & Kontrol \\
\cline { 2 - 4 } & 11 & 11 & 11 \\
\hline Exact Sig. (2-tailed) &, $008^{\mathrm{b}}$ &, $016^{\mathrm{b}}$ &, $500^{\mathrm{b}}$ \\
\hline
\end{tabular}

a. McNemar Test

b. Binomial distribution used.

In non paramteric test with Mcnemar there is difference between before and after giving of lavender scent to insomnia at elderly with value signifikan $0,008<0,05$.

There is difference between before and after giving guided imagery to insomnia in elderly with significant value $0,016<0,05$.

There was no difference between before and after compromise control of insomnia in elderly with significance value $0,500<0,05$.

Thus it can be concluded that among the three treatment groups the greatest effect is the lavender scent with a significant value of $0.008<0.005$. 


\section{DISCUSSION}

\section{A. Insomnia before and after giving the lavender scent to the elderly}

Based on the results of this study showed that from 11 respondents before giving lavender scent the majority experienced insomnia that is as much as 11 respondents $(100 \%)$, and after giving of lavender scent most did not experience insomnia that is as much as 8 respondent $(72,7 \%)$.

This research is in line with research conducted by Lestari (2016) which examined the effect of lavender scent of terapy on decreasing insomnia in elderly at UPT Panti Werdha Mojopahit Mojokerto. From the results of the study showed that from 15 respondents, before giving lavender aromatherapy all had moderate insomnia (100\%) and after giving of lavender aromatherapy almost all of the respondents decreased to mild insomnia 14 respondents $(93,3 \%)$. The data analysis using the wilcoxon sign test states that $\rho=0,000<\alpha=0.05$ thus Ho is rejected and $\mathrm{H} 1$ is accepted. This means that there is an effect of lavender aromatherapy on decreased insomnia in the elderly at UPT Panti Werdha Mojopahit Mojokerto.

Factors causing insomnia according to Pieter, et al (2011) include: a) a psychogenic actor that includes psychic problems in a person such as low self-esteem, feeling removed, useless, until a state of depression; anxiety and excessive fear; and psychological stress associated with marital problems, dissatisfaction in work, financial problems in the family and so forth. b. Physical factors that include work or activity are too long and hard; pain and unpleasant feelings; old age and elderly diseases, such as diabetes mellitus, bronchial asthma, arterio-sclerosis, all of which can lead to insomnia. c. Personality factors, apparently in people with insomnia often there is a certain keperibadian style. Several studies have tried to examine the personality patterns of insomniacs. Apparently $80 \%$ of insomniac patients have 1 or 2 dream scale tends to increase toward pathological, conversion, hysteria, psychopathic deviate and hypochondriasi. These personality forms cause internalization of psychological disorders and can lead to insomnia.

The results showed that before giving aromatherapy the majority experienced insomnia. Insomnia is a condition of the elderly's inability to fall asleep or maintain sleeping conditions characterized by frequent elderly awakening at night and difficult to start sleeping again. Insomnia occurs due to psychological factors such as feeling useless and so on or due to physiological factors such as decreased physical ability, disease that accompanies the elderly and so on.

One effort that can be utilized by the elderly to deal with the problem of insomnia is by giving the scent of lavender that is given with the medium of wax. The lavender aroma is useful for treating insomnia, improving sleep quality, improving sleep in long-term hospital clients, reducing the need for nighttime sedatives, can reduce anxiety and pain. Lavender can also provide peace, balance, comfort, sense of openness, and confidence. In addition, lavender can also reduce stress, stress, pain, unbalanced emotions, hysteria, frustration, and panic. Lavender can be useful for relieving pain and can provide a relaxing effect (Swandari, 2014).

Aromatherapy is one form of relaxation therapy with levender aroma wax media. Lavender flowers containing linalyl acetate and linalool which have anti-anxiety effects (relaxation) in aromatherapy lavender have a positive effect because it is known that the fresh and fragrant aroma can stimulate the sensori and receptors in the nose and then provide further information to areas in the brain that control emotion and memory and provide information to the hypothalamus. The hypothalamus is a regulator of the internal system of the body. Aromatherapy lavender can increase alpha waves in the brain, this wave describes a relaxed state in a person and will disappear when a person's mind or in a busy mental state.

This is in accordance with the results of the study of 11 respondents before giving the scent of lavender to 3 respondents (27.3\%) experienced insomnia after lavender fragrance, meaning there was a decrease of 8 respondents who did not experience insomnia. Thus, it can be concluded that the aroma of lavender therapy can improve the quality of elderly sleep. 


\section{B. Insomnia before and after administration guided imagery on the elderly}

Based on the results of the study showed that from 11 respondents before giving guided imagery the majority experienced insomnia that is as much as 11 respondents (100\%), and after guided imagery most of the insomnia did not experience as many as 7 respondents $(63.6 \%)$.

This research is in line with research conducted by Kusuma (2014) which examines the effectiveness of guided imagery and music therapy techniques to decrease sleep disturbance in elderly at Panti Werda Pelkris Pengayoman Semarang. The results of this study indicate that there are differences in the effectiveness of guided imagery relaxation techniques and music therapy to decrease sleep gangnguan in elderly with a value of $t$ arithmetic of 2.473 with $p$ value of $0.020<0.05$. The level of effectiveness between guided imagery and music therapy is more effective in music therapy because the music therapy obtained by difference before and after 4.64 whereas in guided imagery relaxation technique there is difference before and after 2.21 .

Insomnia is a sleep disorder experienced by patients with symptoms always feel tired, tired throughout the day, constantly having trouble sleeping, always waking up in the middle of the night and difficult to get back to sleep. There are 3 types of insomnia disorders, sleep disorders (sleep onset insomnia), always awakened in the middle of the night (sleep maintenance insomnia), and always wake up much faster than desired (early awakening insomnia). Quite a few people suffer from one of the three types of sleep disorders. In the study it was reported that in the United States there are about $15 \%$ of the total population experiencing serious insomnia (Pieter, 2011).

The results showed that prior to guided imagery the majority experienced insomnia. It is not much different insomnia that occurs in the treatment of good lavender scent marks and causes of insomnia in the elderly. So also with the characteristics of age and gender are correlated with insomnia, not much different from the lavender aroma group. Based on the results of the study showed that of the 11 respondents most of the elderly have age between $70-79$ years as many as 6 respondents (54.5\%) and Based on the results of research indicate that of 11 respondents some types of male sex that is as much as 6 respondents $(54,5 \%)$.

Guided imagery is a relaxation technique that aims to reduce stress and increase calm and peace and is a tranquilizer for a difficult situation in life. Guided imagination or mental imagination is a technique for assessing the power of the mind when consciously or unconsciously to create shadow images that bring peace and silence (National Safety Council, 2012).

Relaxation with guided imagery techniques will make the body more relaxed and comfortable in sleep. By doing deep breath slowly, the body will become more relaxed. Relaxed feelings will be forwarded to the hypothalamus to produce Corticotropin Releasing Factor (CRF). Furthermore, CRF stimulates the pituitary gland to increase the production of proopioid melanocortin (POMC) so that the enkephalin production by the adrenal medulla increases. The pituitary gland also produces endorphins as neurotransmitters that affect the mood to relax. Therefore $\mathrm{p}$ emberian guided imagery aims to distract the elderly against those drivers by imagining something pleasant as guided imagery has an analgesic effect and increases levels of endorphins, and the levels of endorphin itself acts like morphine even said to be bigger than morphine, so to increase endorphin levels by means of relaxation and arousing pleasure with concentration was focusing the mind to the things in like and forget while the problems experienced by the elderly and finally the elderly can sleep well. This is in accordance with the results of research after given guided imagery of 11 respondents who experienced insomnia dropped to 4 respondents. Thus, it can be concluded that guided imagery can improve the quality of elderly sleep.

\section{Insomnia before and after the control group in the elderly}

Based on the results of the study showed that from 11 respondents before the control group the majority experienced insomnia as many as 11 respondents $(100 \%)$, and after treatment (control group) mostly experienced insomnia that is as much as 9 respondents $(81,8 \%)$.

This study is in line with research conducted by So'emah (2015) who examined the effect of lavender floral aromatherapy on the quality of elderly sleep at Dr. RSU. Wahidin Sudiro Husodo 
Mojokerto. The results showed that the quality of sleep in the elderly before lavender aromatherapy given as much as 16 people (100\%) experienced poor sleep quality and after aromatherapy given the lavender flowers in the elderly have increased. Elderly who have excellent sleep quality as many as 6 people $(37.5 \%)$, elderly who have good sleep quality as much as 7 people $(43.75 \%)$ and elderly who experience poor sleep quality as much as 3 people (18.75\%). Wilcoxon test analysis showed the influence of lavender floral aromatherapy on the quality of elderly sleep at Dr. RSU. Wahidin Sudiro Husodo Mojokerto, with the result $\mathrm{p}<\alpha$, where $\mathrm{p}$ value $=0.001$.

Insomnia can have an impact on physical health including increased appetite that can lead to obesity, diabetes, coronary heart disease, hypertension, immune system disorders, and decreased sexual arousal. Insomnia is also associated with psychological disorders such as depression, anxiety, and memory loss because basically sleep is useful for brain resuscitation and memory consolidation (Amir, 2010).

Based on the results of research on the results showed that from 11 respondents before treatment to 9 respondents $(81.8 \%)$. This indicates that without treatment it does not help much elderly in improving the quality of sleep. Should the elderly who experience insomnia given treatment in such a way either treatment using drugs (pharmacology) or without drugs (non pharmacology). But in this control group all elderly at the time of the study were not given any treatment, so insomnia experienced elderly there are some who experience improvement (the more weight). For the elderly who suffered severe sleep disorders and feared to threaten their health by researchers are advised to consume the drug that is CTM. After administration of the drug 2 elderly do not experience insomnia anymore. Thus, the treatment of both lavender scent and guided imagery is very useful for elderly to overcome the problem of sleep disorders. According to Veratama (2017) that the longer using CTM as a sleeping pill, the less likely it is that the CTM can make it drowsy. This is in accordance with the results of research that most of the respondents wake up at midnight, because the effect of drugs in CTM has no effect anymore.

\section{Influence giving of lavender and guided imagery against insomnia in the elderly}

Based on result / output of Cochran test obtained significant probability value equal to 0,032 . Therefore the probability value significantly $0.032<0.05$ then the hypothesis $\mathrm{Ho}$ is rejected and $\mathrm{Ha}$ accepted, meaning there is a very significant influence between the provision of lavender scent and guided imagery against insomnia $\mathrm{p}$ an 1 ansia at UPT Social Service Tresna Werdha Glenmore Banyuwangi District.

The results of this study are similar to the results of previous research conducted by Sari (2017) who examined the effect of lavender therapy on sleep quality elderly in Wisma Cinta Kasih Padang. The results of the study found that all elderly (100\%) had poor sleep quality before lavender aromatherapy and only $40 \%$ experienced poor sleep quality after lavender therapy. The statistical test obtained $\mathrm{p}$ value $=0.000$, where there is influence of lavender therapy to sleep quality of elderly in Wisma Cinta Kasih Padang.

Aging process (aging) is a natural process faced by humans where there is a decrease or changes in physical condition, emotional, psychosocial which will affect its productivity. The condition tends to potentially cause general health problems (physical) and mental health specifically in elderly individuals (Maryam, et al, 2012).

One such disorder is a change in sleep patterns (insomnia), during sleep pattern aging will undergo distinctive changes that distinguish from younger people, those changes include latent phase of sleep, waking up in the early hours, increasing the number of naps and difficulty to sleep that makes the patient feel not getting enough sleep when awakened (Sulistyarini, 2016).

Poor sleep quality (insomnia) can cause disorders such as: more susceptible tendencies to disease, forgetfulness, confusion, disorientation and decreased ability to concentrate and make decisions. This certainly has a negative impact on the quality of life of the elderly. Therefore the problem of sleep quality in the elderly should be addressed immediately (Olivera, 2010).

To overcome the problem of sleep disorders can be done in various ways such as aroma therapy with lavender and guided imagery. The results showed that both treatments were very effective in lowering insomnia. Based on the results of the study showed that of 33 respondents who 
experienced insomnia after giving aroma therapy lavender and guided imagery therapy fell to 16 respondents.

In nonparamterik test with McNemar test there is influence between before and after giving of lavender scent to insomnia in elderly with significant value $0,008<0,05$. There is influence between before and after giving guided imagery to insomnia in elderly with significant value 0,016<0,05. There was no influence between before and after control group against insomnia in elderly with significant value $0,500>0,05$. Thus it can be concluded that among the three treatment groups the greatest effect is the aroma of lavender therapy. While the treatment of guided imagery is less influential because the respondents who become the object of this study are elderly, so that the impact on the hearing tool and lack of concentration so that when the implementation of guided imagery SOP can not run with the maximum.

\section{CONCLUSION}

There was influence between before and after giving of lavender aroma to insomnia in elderly with significant value $0,008<0,05$.

There is influence between before and after giving guided imagery to insomnia in elderly with significant value $0,016<0,05$.

There was no influence between before and after control group against insomnia in elderly with significant value $0,500>0,05$.

There was a significant influence between aromatherapy, guided imagery and control group with insonia at UPT Social Service Tresna Werdha Glenmore Banyuwangi District , where Cochran test results obtained significant probability value of 0.032 . Therefore the probability value is significant $0.032<0.05$.

\section{SUGGESTION}

\section{For respondents}

The results of this study can be maintained and continued for better sleep quality. Whether using aroma therapy or guided imagery lavender because it has been proven to reduce insomnia.

\section{For research sites}

The results of this study may consider the use of complementary therapies both in lowering insomnia using either the scent of lavender or guided imagery according to the conditions and interests of the elderly.

\section{For educational institutions}

The results of this study can be published widely so that it can serve as a reference source in lowering insomnia and can intensify similar research, especially on nonfarmakologi treatment.

\section{For Further Researchers}

The results of this study can serve as evidence-based and additional information to develop further research on the benefits of lavender and guided imagery against the decrease in insomnia. 


\section{REFERENCES}

Amir. N. (2010). Tata Laksana Insomnia Insomnia Bisa Terjadi Pada. Semua Lapisan Usia, Tak Terkecuali Anak-Anak. Jakarta: Bumi Aksara.

Guyton, A., C., \& Hall, J., E. (2010). Buku Ajar Fisiologi Kedokteran. Edisi 9. Jakarta: EGC.

Khasanah, K., \& Hidayati, W. (2012). Kualitas Tidur Lansia Balai Rehabilitasi Sosial "MANDIRI” Semarang. Jurnal Nursing Studies, 1(1) : 189-196.

Kurniawan, \& Tommy. (2012). Faktor-Faktor Yang Mempengaruhi Gangguan Tidur (Insomnia) Pada Lansia Di Panti Tresna Werdha Kabupaten Magetan. http://scholar.google. com/scholar.

Kusuma, R., P. (2014). Efektifitas teknik relaksasi imajinasi terbimbing (guided imagery) dan terapi musik terhadap penurunan gangnguan tidur pada lansia di Panti Werda Pelkris Pengayoman Semarang. http://ejournal.stikestelogorejo.ac.id/index.php/ilmukeperawatan/article/view/188/212.

Lestari, Y., T. (2016). Pengaruh Pemberian Lavender Aromatherapy Terhadap Penurunan Insomnia Pada Lanjut Usia Di UPT Panti Werdha Mojopahit Mojokerto. https://jurnalperawat.stikespemkabjombang ac.id/.

Luthfa, I., Khasanah, F., Wiji, P., S., D. (2015). Terapi Musik Rebana Mampu Menurunkan Tingkat Stres Pada Lansia Di Unit Pelayanan Sosial Pucang Gading Semarang. Jurnal Keperawatan dan Pemikiran Ilmiah; 1 (2). $1-7$.

Maryam, S., dkk. (2012). Mengenal usia lanjut dan perawatannya. Jakarta: Salemba Medika.

National Sleep Foundation. (2012). New Research: Identify and Treat Insomnia Early to Reduce Risk of Other Illnesses. http://www.sleepfoundation.org/ alert/new-research-identify-and-treatinsomnia-early-reduce-riskother-illnesses.

Oliveira, A. (2010). Sleep Quality of Elders Living in Long-Term Care. Institutions. http://www.scielo.br/pdf/reeusp/v44n3/en_10.pdf.

Prasetya, Z. (2016). Pengaruh Terapi Relaksasi Otot Progressif Terhadap Perubahan Tingkat Insomnia Pada Lansia. http://repositori.uin-alauddin.ac.id/2157/1/Ahmad\%20Lutfi\%20Karim.PDF.

Sari, D. (2017). Pengaruh terapi lavender terhadap kualitas tidur lansia di Wisma Cinta Kasih Padang. http://ejournal.kopertis10.or.id/ index.php/endurance/article/view/2433.

Sianipar, K. (2017). Pengaruh aromatherapi, relaksasi oto progresif terhadap penurunan kecemasan ibu hamil menjelang Persalinan Di BPM Simalungun. http://pannmed .poltekkes-medan.ac.id/files/2017/Mei-Agu/ Panmed\%20mei\%202017_Kandace.pdf.

So'emah, E., N. (2015). Pengaruh aromaterapi bunga lavender terhadap kualitas tidur lansia di RSU dr. Wahidin Sudiro Husodo Mojokerto. http://ejournal.stikes-ppni.ac.id/index.php/keperawatan-bina-sehat/article/view/132.

Sulistyarini. (2016). Gambaran Karakteristik Lansia dengan Gangguan Tidur (Insomnia) di RW 1 Kelurahan Bangsal Kota Kediri. http://ejurnal.stikes baptis.ac.id/index.php/ keperawatan/article/download/139/11.

Swandari, P. (2014). Perbedaan Tingkat Nyeri Before dan After Pemberian Aromaterapi Lavender pada Ibu Post Sectio Caesarea di RSUD Ambarawa. Perbedaan Tingkat Nyeri Before dan After Pemberian Aromaterapi Lavender pada Ibu Post Sectio Caesarea di RSUD Ambarawa , 1-9.

Zan, P., H., dkk. (2011). Pengantar Psikologi untuk Kebidanan, Jakarta: Kencana Prenada Media Group.

Zeidler, M., R. (2011). Insomnia. Editor: Selim R Benbadis. http://emedicine.medscape.com/ article/1187829overview. 
Analysis of Lavender Aroma and Guided Imagery on Insomnia..... 